\title{
Koetuloksia säilörehunurmien typpilannoituksesta saraturvesuolla
}

\author{
HEIKKI LUOSTARINEN \\ Suoviljelysyhdistys, Tohmajärvi \\ Results of nitrogen fertilization of leys on sedge peat
}

\author{
Heikki Luostarinen \\ Society of Peat Cultivation, Tohmajärvi
}

\begin{abstract}
Nitrogen fertilizing of timothy and meadow fescue ley harvested as silage was studied on woody sedge peat in field tests arranged at the Karelia Experiment Station in North Karelia in $1970-73$.

The nitrogen $(0,150,300$ and $450 \mathrm{~kg} / \mathrm{ha} \mathrm{N})$ was given as calcium ammonium nitrate fertilizer in three equal amounts during the period of growth. The yearly amount of the potash fertilizing was $100+50 \mathrm{~kg} / \mathrm{ha} \mathrm{K}$ and that of the phosphate fertilizing 44 $\mathrm{kg} / \mathrm{ha} \mathrm{P}$.

The average dry matter yield $(y=t / h a)$ was represented by the equation $y=4.97$ $+2.07 \mathrm{x}-0.30 \mathrm{x}^{2}$, and the average crude protein yield $(\mathrm{y}=\mathrm{t} / \mathrm{ha})$ by the equation $y=0.720+0.462 x-0.0521 x^{2}$ with $x=100 \mathrm{~kg} / \mathrm{ha} \mathrm{N}$. In first year leys nitrogen increased the yields most effectively, but in ageing leys the yield increases with large nitrogen amounts decreased. This was chiefly due to the natural thinning of the leys mainly during the winter.

Nitrogen fertilizing effectively increased the crude protein contents of the grass and altered the mineral matter composition.

Cultivation of the ley using strong nitrogen fertilizing clearly affected the potassium and calcium condition of the soil. Since the leys apparently absorbed potassium more than was necessary for their growth.

The advisable nitrogen fertilizing was $220-240 \mathrm{~kg} / \mathrm{ha} \mathrm{N}$.
\end{abstract}

\section{Johdanto}

Lukuisat niittonurmien typpilannoitusta koskevat tutkimukset ovat osoittaneet, että turvemailla typpilannoitus lisää tehokkaasti heinä- ja odelmasatoa sekä kohottaa rehun valkuaispitoisuutta (TEnnberg 1955, SALONEN ym. 1962, Tennberg ja VAlmari 1969). Ainoastaan parhailla Etelä-Suomen mutasoilla typpilannoituksen tarve niittonurmilla on ollut vähäistä (PEssI 1966).

Heinäkasvivaltaisille säilörehunurmille käytetään huomattavasti suurempia typpimääriä kuin niittonurmille. Tällaisten nurmien typpilannoituksesta 
suoviljelyksillä on julkaistu koetuloksia vähemmän kuin niittonurmilta. Maatalouden tutkimuskeskuksen toimesta v. 1967-70 järjestetyissä kokeissa typen vaikutus säilörehunurmen satoon oli turvemailla samanlainen kuin kivennäismailla (JÄNTTI 1967, HUOKUNA 1971, 1973), mutta sadon kivennäisainepitoisuuksissa ja maan ravinnetilan mutoksissa voitiin todeta maalajikohtaisia eroja (RıNne 1973, SillańPÄÄ 1974). Näissä kokeissa turvemaita koskevat tulokset oli saatu Leteensuon koeaseman rahkaturpeella sekä Pohjois-Suomen saraturvesoilla.

Tässä kirjoituksessa käsitellään säilörehuasteella korjattavan heinäkasvinurmen typpilannoitusta saraturvesuolla. Koeaineisto saatiin Suoviljelysyhdistyksen Karjalan koeasemalla Tohmajärvellä v. 1970-73 järjestetyissä kenttäkokeissa. Artikkelissa tarkastellaan typpilannoituksen vaikutusta nurmen talvehtimiseen, satoon, sadon laatuun ja maaperään sekä tehdään joitakin selvityksiä typpilannoituksen taloudellisuudesta.

\section{Aineisto}

Koenurmet perustettiin metsäsaraturpeelle, jonka maatumisaste oli $\mathrm{H}$ 8-9. Koealueilla oli käytetty maanparannusaineena hietaa tai hiekkaa 200 $\mathrm{m}^{3} /$ ha 1920 - ja 30-luvuilla. Turpeiden tuhkapitoisuus oli koemaissa $43-55 \%$ ja tilavuuspaino muokkauskerroksessa $420-520 \mathrm{~g} / \mathrm{l}$. Soiden pintaosa muistutti siis multamaita, joista turpeen tuntomerkit alkoivat olla jo vaikeasti todettavissa. Koealueiden viljavuusluvut käyvät selville jäljempänä tässä esityksessä.

Koenurmille annettiin vuotuislannoituksena $500 \mathrm{~kg} / \mathrm{ha}$ superfosfaattia $\left(20 \% \mathrm{P}_{2} \mathrm{O}_{5}\right)$ ja $200 \mathrm{~kg} /$ ha kalisuolaa $\left(60 \% \mathrm{~K}_{2} \mathrm{O}\right)$ keväällä sekä toisen niiton jälkeen $100 \mathrm{~kg} /$ ha kalisuolaa. Typpi levitettiin kolmessa yhtä suuressa erässä, ensimmäinen levitys keväällä nurmien alkaessa kasvunsa tai vähän sitä aikaisemmin, toinen levitys ensimmäisen ja kolmas toisen niiton jälkeen. Typpitasot olivat $0,150,300$ ja $450 \mathrm{~kg} / \mathrm{ha}$ typpeä oulunsalpietarina $(26-27.5 \%$ $\mathrm{N}, 3 \% \mathrm{Mg})$.

Kokeet perustettiin timotei- (lajike Tammisto) ja nurminatanurmille (lajike Paavo) lohkoittain satunnaistettua koemallia käyttäen. Kokeita oli kaikkiaan neljä, joista yhdessä oli kolme kerrannetta ja muissa neljä. Koeruudun koko oli $2.5 \times 8$ metriä. Ensimmäinen koe perustettiin v. 1970, kaksi koetta seuraavana ja yksi sitä seuraavana vuonna. Jälkimmäisestä kokeesta saatiin koetulokset vain kahdelta vuodelta. Muut kokeet jatkuivat kolmen vuoden ajan.

Kasvustot korjattiin säilörehuasteella kolme kertaa kesässä. Niitot pyrittiin tekemään viimeistään silloin, kun ensimmäiset tähkät ja röyhyt alkoivat tulla esiin lehtitupeista, mitä korjuuajankohtaa mm. Poutiarnen ja Rinne (1971) pitävät sopivana. Aikaisimman ja myöhäisimmän niiton ajankohdat olivat ensimmäisessä korjuussa $12 / 6-21 / 6$, toisessa $17 / 7-28 / 7$ ja kolmannessa $2 / 9-13 / 9$. Jokaisella niittokerralla otettiin koeruuduittain ruohonäytteet, joista määritettiin kuiva-aine ja tehtiin botaaninen analyysi. Sen perusteella satotulokset laskettiin kylvetyn kasvin antamiksi sadoiksi. Ilmakuiviksi kuivatetuista näytteistä määritettiin ruohon ravinnepitoisuudet Viljavuuspalvelu 
Taulukko 1. Sâäolot Tohmajärvellä 1970-73.

Table 1. Weather conditions at Tohmajärvi 1970-73.

\begin{tabular}{|c|c|c|c|c|c|c|c|c|c|c|c|}
\hline \multirow{2}{*}{\multicolumn{2}{|c|}{$\begin{array}{l}\text { Kuukausi } \\
\text { Month }\end{array}$}} & \multicolumn{3}{|c|}{$\begin{array}{c}\text { Sademäärä, mm } \\
\text { Rainfall, } m m\end{array}$} & \multirow[b]{2}{*}{1973} & \multirow{2}{*}{$\begin{array}{c}\text { Norm. } \\
\text { Normal } \\
1931 \text { - } \\
60\end{array}$} & \multicolumn{3}{|c|}{$\begin{array}{l}\text { Lämpötila, } \mathrm{C}^{\circ} \\
\text { Temperature, } C^{\circ}\end{array}$} & \multirow[b]{2}{*}{1973} & \multirow{2}{*}{$\begin{array}{c}\text { Norm. } \\
\text { Normal } \\
1931- \\
60\end{array}$} \\
\hline & & 1970 & 1971 & 1972 & & & 1970 & 1971 & 1972 & & \\
\hline V & ... & 18 & 18 & 30 & 46 & 39 & 8.1 & 7.4 & 7.8 & 9.4 & 7.7 \\
\hline VI & ........ & 10 & 33 & 23 & 79 & 57 & 15.6 & 12.5 & 16.2 & 16.1 & 13.4 \\
\hline VII & ........ & 92 & 64 & 57 & 29 & 74 & 16.5 & 15.2 & 19.2 & 18.2 & 16.1 \\
\hline VIII & ............... & 66 & 73 & 75 & 53 & 74 & 13.7 & 13.9 & 16.1 & 13.4 & 13.9 \\
\hline IX & .............. & 73 & 39 & 43 & 92 & 66 & 8.6 & 7.0 & 8.3 & 4.8 & 8.6 \\
\hline
\end{tabular}

Oy:ssä. Samassa laitoksessa analysoitiin myös maanäytteiden ravinnepitoisuudet.

Kesäkuukausien sääolot v. 1970-73 nähdään taulukosta 1. Alkukesä oli yleensä vähäsateista ja vain vuonna 1973 kesäkuun sademäärä ylitti normaalin (57 mm). Kesäkuun alku oli tällöinkin hyvin vähäsateinen ja samoin heinäkuu.

\section{Tulokset ja niiden tarkastelu}

\section{a. Nurmien talvehtiminen}

Kun nurmien säilyminen riittävän tiheinä on keskeinen kysymys nurmiviljelyssä, tarkastellaan seuraavassa lyhyesti nurmien tiheyksien muutoksia kolmen koevuoden aikana. Keskimääräiset tiheysprosentit kasvilajeittain nähdään seuraavasta asetelmasta.

\begin{tabular}{|c|c|c|c|c|c|c|}
\hline \multirow{2}{*}{$\begin{array}{l}\mathrm{N} \\
\mathrm{kg} / \mathrm{ha}\end{array}$} & \multirow{2}{*}{$\begin{array}{l}\text { 1. nurmi } \\
\text { syksy }\end{array}$} & \multicolumn{2}{|c|}{ 2. nurmi } & \multicolumn{2}{|c|}{ 3. nurmi } & \multirow{2}{*}{$\begin{array}{l}\text { 4. nurmi } \\
\text { kevät }\end{array}$} \\
\hline & & kevät & syksy & kevăt & syksy & \\
\hline \multicolumn{7}{|c|}{ Timotein tiheys, \% } \\
\hline 0 .................. & 95 & 85 & 91 & 84 & 87 & 81 \\
\hline $150 \ldots \ldots \ldots \ldots$ & 89 & 78 & 84 & 79 & 79 & 75 \\
\hline $300 \ldots \ldots \ldots \ldots$ & 84 & 68 & 79 & 70 & 75 & 71 \\
\hline $450 \ldots \ldots \ldots \ldots$ & 83 & 58 & 75 & 68 & 75 & 70 \\
\hline \multicolumn{7}{|c|}{ Nurminadan tiheys, $\%$} \\
\hline 0 ….............. & 90 & 86 & 92 & 87 & 93 & 84 \\
\hline $150 \ldots \ldots \ldots$ & 88 & 83 & 89 & 77 & 90 & 76 \\
\hline $300 \ldots \ldots \ldots \ldots$ & 84 & 78 & 87 & 77 & 85 & 60 \\
\hline $450 \ldots \ldots \ldots \ldots$ & 83 & 70 & 87 & 77 & 85 & 57 \\
\hline
\end{tabular}

Nurmien tiheydet olivat ensimmäisen vuoden keväällä samoja eri koejäsenillä, mutta syksyyn mennessä nurmet harvenivat typpilannoituksen vaikutuksesta. Harvenemista saattoi osaltaan edistää käsin tapahtunut lannoitteiden levitys, jolloin lannoitteita ei saatu riittävän tasaisesti nurmille useam- 
masta osalevityksestä huolimatta. Toisaalta myös nurmien tihenemistä tapahtui kasvukauden kuluessa erityisesti nurminatanurmilla.

Typpilannoitus lisäsi selvästi talvituhoja. Käytettäessä $300 \mathrm{~kg} / \mathrm{ha}$ typpeä tai enemmän monia koenurmia ei olisi kannattanut pitää kolmea vuotta vanhemmiksi. Joissakin kokeissa nurmien viimeisen niiton ajankohta saattoi jäädä liian myöhäiseksi (vrt. HUOKuNA 1971), mikä osaltaan voi lisätä talvehtimisvaurioita. Talvikaudet olivat kuitenkin koejakson aikana yleensä suotuisia.

\section{b. Sadot}

Taulukkoon 2 on koottu typpilannoituskokeissa saadut keskimääräiset kuiva-aine- ja raakavalkuaissadot niittokerroittain. Kuiva-ainesadon nousu typpilannoitusta lisättäessä pysähtyi noin 300 typpikilon kohdalla. Kevätsato oli suurin ja tällöin myös typen vaikutus oli tehokkainta. Keskikesällä sato jäi pienemmäksi kuin muilla korjuukerroilla. Jos näitä tuloksia verrataan maatalouden tutkimuskeskuksen toimesta v. 1967-70 järjestettyjen säilörehunurmien typpilannoituskokeiden tuloksiin (HUOKUNA 1973), jotka pääasiassa oli saatu kivennäismailta, voidaan todeta, että satotaso 300 typpikilon lannoituksella oli keskimäärin sama, mutta saraturvesuolla satokäyrä oli loivempi erityisesti O- tason satotuloksen noustessa selvästi korkeammaksi kuin kivennäismailla.

Raakavalkuaissato kohosi suurimpaan käytettyyn typpimäärään saakka, mutta ei kuitenkaan suoraviivaisesti. Viimeisellä lannoitusvälillä $(300-450$ $\mathrm{kg} / \mathrm{ha} \mathrm{N}$ ) saatiin typpikilolla keskimäärin vain $0.8 \mathrm{~kg} / \mathrm{ha}$ raakavalkuaista, kun vastaava sadonlisäys ensimmäisellä lannoitusvälillä oli $4.0 \mathrm{~kg} / \mathrm{ha}$.

Taulukko 2. Keskimääräiset kuiva-aine- ja raakavalkuaissadot (kg/ha) 1970-73.

Table 2. Average dry matter and crude protein yields (kg/ha) 1970-73.

\begin{tabular}{|c|c|c|c|c|}
\hline $\begin{array}{c}\mathrm{N} \\
\mathrm{kg} / \mathrm{ha}\end{array}$ & $\begin{array}{l}\text { 1. niitto } \\
\text { 1st cut }\end{array}$ & $\begin{array}{l}\text { 2. niitto } \\
2 n d \text { cut }\end{array}$ & $\begin{array}{l}\text { 3. niitto } \\
\text { 3rd cut }\end{array}$ & $\begin{array}{c}\text { Yhteensä }^{\mathbf{1}} \text { ) } \\
\left.\text { Total }^{\mathbf{1}}\right)\end{array}$ \\
\hline & Kuiva-aine - Dry & matter & & \\
\hline 0 (n.......................... & 1990 & 1170 & 1720 & $4880 \pm 346$ \\
\hline 150 & 2950 & 1950 & 2710 & $7610 \pm 279$ \\
\hline 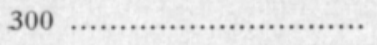 & 3320 & 2080 & 2870 & $8270 \pm 321$ \\
\hline 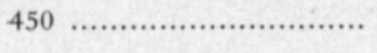 & 3320 & 2220 & 2780 & $8320 \pm 412$ \\
\hline & Raakavalkuainen & - Crude protein & & \\
\hline 0 & 264 & 178 & 277 & $719 \pm 57$ \\
\hline 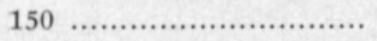 & 452 & 368 & 492 & $1312 \pm 55$ \\
\hline 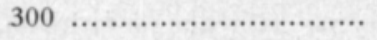 & 595 & 443 & 594 & $1632 \pm 52$ \\
\hline 450 .............................. & 657 & 504 & 591 & $1752 \pm 70$ \\
\hline
\end{tabular}

1) Keskiarvo \pm keskivirhe $\mathrm{s}_{\mathrm{x}}^{-}(\mathrm{n}=10)$

1) Mean \pm standard error $s_{\mathbf{x}}^{-}(N=10)$ 
Taulukko 3. Kuiva-aine- ja raakavalkuaissadot $(\mathrm{kg} / \mathrm{ha})$ eri ikäisillä nurınilla $1970-73$.

Table 3. Dry matter and crude protein yields ( $\mathrm{kg} / \mathrm{ha}$ ) of different aged leys 1970-73.

\begin{tabular}{|c|c|c|c|c|c|c|}
\hline \multirow{2}{*}{$\begin{array}{c}\mathrm{N} \\
\mathrm{kg} / \mathrm{ha}\end{array}$} & \multicolumn{3}{|c|}{ Kuiva-aine - Dry matter } & \multicolumn{3}{|c|}{ Raakavalkuainen - Crude protein } \\
\hline & $\begin{array}{l}\text { 1. nurmi } \\
\text { 1st ley }\end{array}$ & $\begin{array}{l}\text { 2. nurmi } \\
2 \text { nd ley }\end{array}$ & $\begin{array}{l}\text { 3. nurmi } \\
\text { 3rd ley }\end{array}$ & $\begin{array}{l}\text { 1. nurmi } \\
\text { 1st ley }\end{array}$ & $\begin{array}{l}\text { 2. nurmi } \\
\text { 2nd ley }\end{array}$ & $\begin{array}{l}\text { 3. nurmi } \\
\text { 3rd ley }\end{array}$ \\
\hline 0 ............. & 4340 & 5650 & 4860 & 606 & 829 & 764 \\
\hline $150 \ldots \ldots \ldots \ldots$ & 7600 & 8020 & 7470 & 1277 & 1387 & 1283 \\
\hline $300 \ldots \ldots \ldots \ldots$ & 8640 & 8480 & 7550 & 1659 & 1731 & 1462 \\
\hline $450 \ldots \ldots \ldots \ldots$ & 8840 & 8470 & 7470 & 1865 & 1816 & 1536 \\
\hline $\begin{array}{l}\text { F-arvot } \ldots . . . \\
\text { F-values }\end{array}$ & $43.39 * * *$ & $26.03 * * *$ & $127.67 * * *$ & $74.50 * * *$ & $60.99 * * *$ & $149.01 * * *$ \\
\hline $\begin{array}{l}\text { PME .......... } \\
\text { L.S.D. }\end{array}$ & 1162 & 915 & 392 & 231 & 191 & 99 \\
\hline
\end{tabular}

Satotulokset nurmen iän mukaan ryhmiteltyinä nähdään taulukosta 3 . Typen vaikutus oli tehokkainta ensimmäisen vuoden nurmissa. Tällöin saatiin lannoitusvälillä $150-300 \mathrm{~kg} /$ ha N kuiva-ainesadon lisäystä yhdellä typpikilolla keskimäärin $6.9 \mathrm{~kg} / \mathrm{ha}$, toisen vuoden nurmissa $3.1 \mathrm{~kg} / \mathrm{ha}$ ja kolmannen vuoden nurmissa vain $0.5 \mathrm{~kg} / \mathrm{ha}$. Kolmannen vuoden nurmissa sato oli vielä lähes yhtä korkea kuin ensimmäisen vuoden nurmissakin käytettäessä $150 \mathrm{~kg} / \mathrm{ha}$ typpeä, mutta suuremmilla typpimäärillä se laski selvästi koejakson aikana. Typen vaikutus oli tehokkainta kevätkesällä nurmen iästä riippumatta.

Raakavalkuaissato nousi vielä kolmannen vuoden nurmissakin suurimpaan käytettyyn lannoitemäärään saakka, mutta sadonlisäykset olivat merkitseviä vain 300 typpikilon tasolle.

Timotein ja nurminadan keskimääräiset satotulokset nähdään seuraavasta asetelmasta:

\begin{tabular}{|c|c|c|c|c|}
\hline Kasvilaji & $0 \mathrm{~N}$ & $150 \mathrm{~N}$ & $300 \mathrm{~N}$ & $450 \mathrm{~N}$ \\
\hline \multicolumn{5}{|c|}{ Kuiva-ainesato, $\mathrm{kg} / \mathrm{ha}$} \\
\hline Timotei ........................ & 5440 & 7770 & 8370 & 8350 \\
\hline 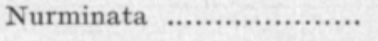 & 4070 & 7380 & 8110 & 8270 \\
\hline \multicolumn{5}{|c|}{ Raakavalkuaissato, $\mathrm{kg} / \mathrm{ha}$} \\
\hline Timotei ......................... & 800 & 1350 & 1630 & 1770 \\
\hline Nurminata .................... & 600 & 1260 & 1640 & 1730 \\
\hline
\end{tabular}

Ilman typpilannoitusta timotein sato oli suurempi kuin nurminadan, mutta typpilannoitusta käytettäessä satoerot jäivät pieniksi.

\section{c. Ruohon laatu}

Ruohon keskimääräiset kuiva-aineen, raakavalkuaisen, kuidun ja tuhkan pitoisuudet sekä keskiarvojen luotettavuusrajat 95 prosentin todennäköisyydelle laskettuina on esitetty taulukossa 4. Typpilannoitus alensi ruohon kuivaainepitoisuutta voimakkaimmin ensimmäisen niittokerran sadossa. Myöhem- 
Taulukko 4. Ruohon kuiva-aineprosentit sekä raakavalkuaisen, kuidun ja tuhkan osuudet, $\%$ kuiva- aineesta $\left.{ }^{1}\right)$.

Table 4. Dry matter percentages of grass and crude protein, fibre and ash contents, $\%$ of DM. ${ }^{1}$ )

\begin{tabular}{cccc}
\hline $\mathrm{N}$ & 1. niitto & 2. niitto & 3 niitto \\
$\mathrm{kg} / \mathrm{ha}$ & 1 st cut & 2 nd cut & 3 rd cut \\
\hline
\end{tabular}

$\begin{array}{ccc}0 & \ldots \ldots \ldots \ldots \ldots \ldots \ldots \ldots \\ 150 & \ldots \ldots \ldots \ldots \ldots \ldots \ldots \ldots \ldots \ldots \\ 300 & \ldots \ldots \ldots \ldots \ldots \ldots \ldots \ldots \ldots\end{array}$

$19.6 \pm 2.1$
$17.1 \pm 1.2$
$16.6 \pm 0.8$
$16.3 \pm 0.9$

Kuiva-aine - Dry matter

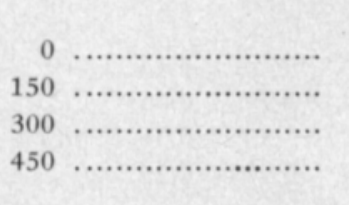

\begin{tabular}{lll}
\multicolumn{3}{c}{ Raakavalkuainen - Crude protein } \\
$13.3 \pm 1.7$ & $14.9 \pm 1.2$ & $16.4 \pm 1.1$ \\
$15.3 \pm 1.2$ & $19.2 \pm 1.6$ & $18.3 \pm 1.5$ \\
$18.1 \pm 1.8$ & $21.7 \pm 1.1$ & $21.1 \pm 2.2$ \\
$20.0 \pm 1.4$ & $22.8 \pm 2.1$ & $21.6 \pm 1.9$
\end{tabular}

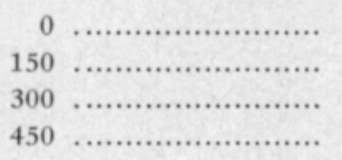
$27.2 \pm 2.4$
$27.7 \pm 2.2$
$27.0 \pm 2.2$
$27.3 \pm 2.0$

$21.5 \pm 2.0$
$19.0 \pm 2.1$
$18.9 \pm 2.2$

$18.7 \pm 2.2$

$16.9 \pm 2.6$

$16.9 \pm 3.0$

$18.9 \pm 2.2$

$16.8 \pm 2.8$

Kuitu - Fibre
$25.0 \pm 1.5$
$25.9 \pm 1.5$
$26.1 \pm 1.1$
$26.8 \pm 1.4$

$24.2 \pm 1.3$

$25.0 \pm 1.4$

$23.9 \pm 1.7$

$23.7 \pm 2.0$

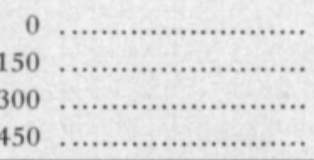
$8.2 \pm 0.9$
$8.7 \pm 0.5$
$8.6 \pm 0.8$
$8.6 \pm 1.2$
Tuhka - Ash
$10.0 \pm 1.3$
$9.6 \pm 0.7$
$8.9 \pm 1.1$
$9.4 \pm 1.1$
$9.8 \pm 0.7$
$9.3 \pm 0.6$
$9.2 \pm 1.2$

$8.9 \pm 1.2$

1) Luotettavuusrajat $95 \%$ tasolla.

1) Confidence limits at the $95 \%$ level.

missä niitoissa kuiva-ainepitoisuuksien erot eri typpitasoilla jäivät pieniksi. Keskiarvojen luotettavuusrajat olivat syksyllä korjatussa sadossa suuremmat kuin muilla niittokerroilla, mikä viittaa siihen, että korjuuoloihin joudutaan kohdistamaan suurta huomiota pyrittäessä rehun kuiva-ainepitoisuus saamaan mahdollisimman korkeaksi. Tällä seikallahan on vaikutusta mm. säilöntätappioiden suuruuteen (ETTALA ym. 1972).

Typpilannoitus lisäsi voimakkaasti ruohon raakavalkuaispitoisuutta kaikilla niittokerroilla. Alhaisimmat raakavalkuaispitoisuudet todettiin ensimmäisessä sadossa. Kasvustojen erilainen kehitysaste saattoi osaltaan vaikuttaa tähän, muttei kuitenkaan yksinomaisesti. Typen tarvehan oli suurinta kevätkesällä myös sadonlisäyksistä päätellen.

Ruohon kuitupitoisuus oli korkein ensimmäisen niittokerran sadossa ja tällöin myös pitoisuuksien vaihtelu oli voimakkainta. Korjuuajankohta myöhästyi helpoimmin juuri tällöin nurmien nopean kasvun vaiheessa. Typpilannoitus alensi lievästi kuitupitoisuutta, mikä tuli kuitenkin näkyviin vasta kasvilajeittain asiaa tarkasteltaessa.

Kuiva-aineen tuhkapitoisuus aleni typpilannoituksen vaikutuksesta toisessa ja kolmannessa niitossa (taulukko 4). Tuhkapitoisuuden vaihtelut tulivat 
Taulukko 5. Ruohon kivennäisaineiden, nitraatin ja tuhkan pitoisuudet, $\%$ kuiva-aineesta. Table 5. Contents of minerals, nitrate, and ash in grass, $\%$ of DM.

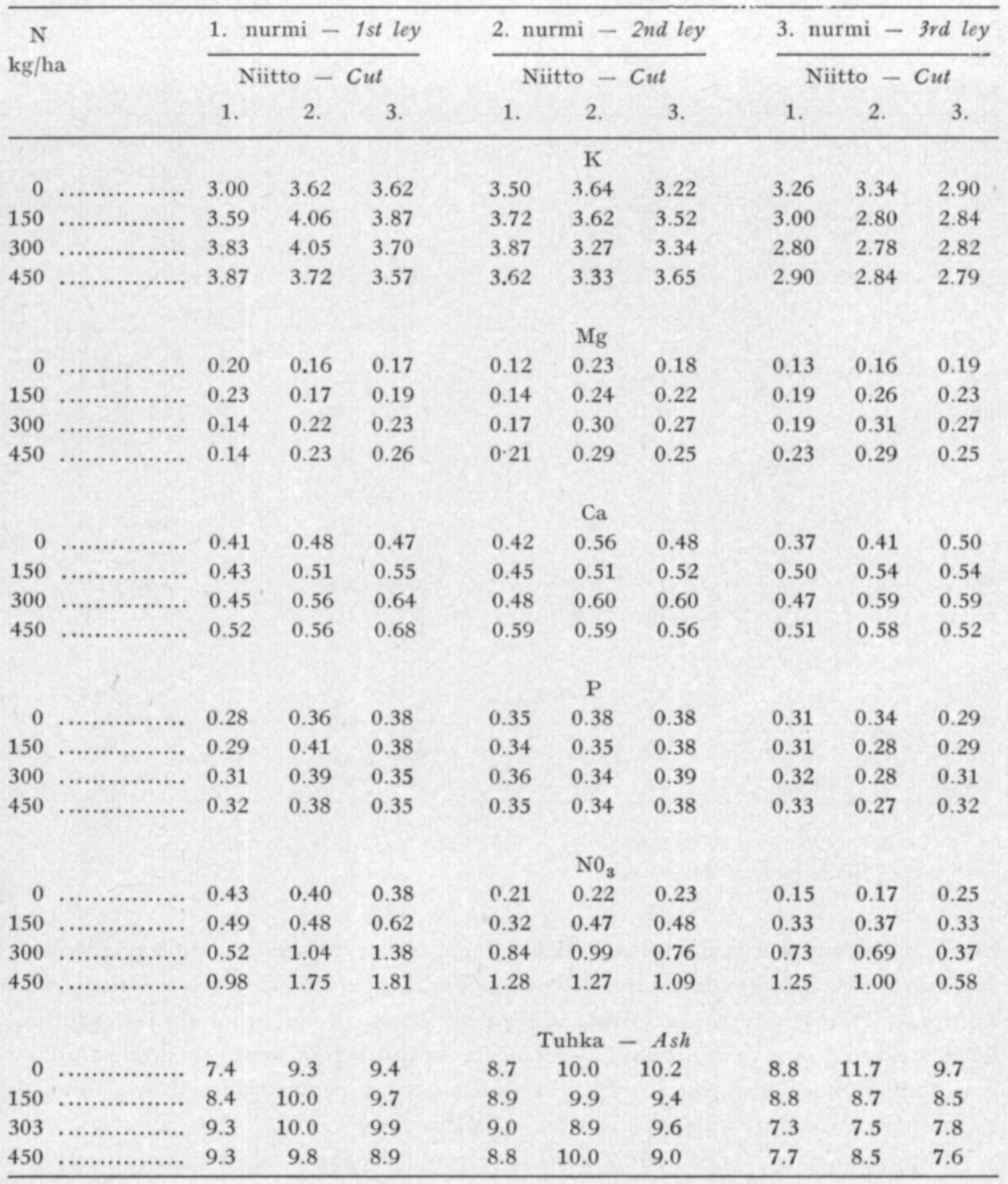

kuitenkin selvemmin esille nurmen iän mukaan ryhmiteltyinä (taulukko 5). Typpilannoitus siis lisäsi tuhkapitoisuutta ensimmäisen vuoden nurmissa ja vähäisemmässä määrin myös toisen vuoden nurmien ensimmäisessä sadossa mutta alensi sitä kolmannen vuoden nurmissa.

Ruohon kuiva-aineen kivennäispitoisuudet on ryhmitelty nurmen iän mukaan (taulukko 5). Kaliumin osalta voidaan todeta, että ensimmäisen vuoden nurmien kevätsadon ja toisen sadon sekä toisen vuoden nurmien ensimmäisen sadon kaliumpitoisuus nousi typpilannoituksen vaikutuksesta. Myöhemmin typpilannoituksen noustessa kaliumin pitoisuudet alenivat. 
Lannoituksena annetun kaliumin $\left(\mathrm{K}_{1}=150 \mathrm{~kg} / \mathrm{ha} \mathrm{K}\right)$ ja satojen mukana poistuneen kaliumin $\left(\mathrm{K}_{\mathrm{s}}\right)$ taseet, jotka siis kuvastavat maaperän kalivarojen vähenemistä, nähdään seuraavasta asetelmasta:

\begin{tabular}{lcccc}
\hline $\begin{array}{l}\mathrm{N} \\
\mathrm{kg} / \mathrm{ha}\end{array}$ & 1. nurmi & $\begin{array}{c}\mathrm{K}_{\mathrm{l}}-\mathrm{K}_{\mathrm{s}}, \mathbf{k g} / \mathrm{ha} \\
\text { 2. nurmi }\end{array}$ & 3. nurmi & Yht. \\
\hline & & & & \\
\hline & & -44 & -5 & -51 \\
& -140 & -141 & -68 & -349 \\
& -182 & -146 & -62 & -390 \\
\hline
\end{tabular}

Käytettäessä $150-450 \mathrm{~kg} / \mathrm{ha} \mathrm{N}$ poistui satojen mukana kaliumia suuruusluokaltaan samanlaiset määrät kolmen koevuoden aikana. Kahtena ensimmäisenä vuotena sadot ottivat kasvukaudessa noin kaksi kertaa vuotuislannoitusta vastaavan määrän kaliumia, mutta jo kolmannen vuoden nurmissa kulutus oli oleellisesti laskenut.

Ruohon magnesiumpitoisuudet olivat alhaisimmat yleensä kevätkesän sadoissa (taulukko 5). Myöhemmin typpilannoitus lisäsi ruohon magnesiumpitoisuutta. Ruohon kalsiumin osuus puolestaan nousi lievästi typpilannoituksen vaikutuksesta. Maatalouden tutkimuskeskuksen kokeissa v. 1967-70 typpilannoitus ei juuri vaikuttanut turvemailla ruohon kalsiumpitoisuuteen (vrt. Rinne 1973). Ruoho sisälsi kalsiumia ja fosforia lypsylehmien tarpeeseen nähden niukanlaisesti vastaavasti kuten tutkimuskeskuksen kokeissakin.

Ruohon nitraattipitoisuuksien määrityksiä tehtiin vain vuosina 1972 ja -73. Saadut tulokset esitetään kuitenkin nurmen iän mukaan ryhmiteltyinä (taulukko 5). Typpilannoitus nosti voimakkaasti ruohon nitraattipitoisuutta kaikilla niittokerroilla. Käytettäessä $50 \mathrm{~kg} /$ ha typpeä niittokertaa kohti nitraattipitoisuus ei keskimäärin ylittänyt $0.5 \%$ kuiva-aineessa. Korkein todettu nitraattipitoisuus tällä lannoituksella oli $0.75 \%$ kuiva-aineessa.

\section{d. Vaikutukset maaperään}

Koemaiden ravinnepitoisuudet määritettiin kokeiden päätyttyä viljavuustutkimuksessa käytettyjen analyysimenetelmien mukaisesti (vrt. KURKI ym. 1965). Keskimääräiset analyysitulokset nähdään taulukosta 6 .

Vaikka vaihtuvan kalsiumin pitoisuus laski typpilannoituksen vaikutuksesta, pH:n aleneminen oli vähäistä. Fosforiluvut alenivat typpilannoituksen noustessa. Typpilannoituksen vaikutus maan boorin, kuparin ja magnesiumin määriin jäi vähäiseksi.

Edellä todettiin jo, että kaliumin nettovähennys kolmen koevuoden aikana oli käytettäessä $300 \mathrm{~kg} / \mathrm{ha}$ typpeä $390 \mathrm{~kg} / \mathrm{ha} \mathrm{K}$, mikä oli $339 \mathrm{~kg}$ suurempi kuin ilman typpilannoitusta. Vaihtuvan kaliumin vähennys oli vastaavasti $69 \mathrm{mg} / 1$ suurempi, mikä laskettuna hehtaaria kohti $20 \mathrm{~cm}$ :n kerroksessa ei vastaa satojen mukana poistunutta kaliummäärää. Vaikealiukoista kaliumia oli 
Taulukko 6. Maaperän viljavuusluvut.

Table 6. Average soil testing results.

\begin{tabular}{|c|c|c|c|c|c|c|c|c|}
\hline $\begin{array}{c}\mathrm{N} \\
\mathrm{kg} / \mathrm{ha}\end{array}$ & $\begin{array}{c}\text { Johtoluku } \\
\text { Spec, conductivity }\end{array}$ & $\mathrm{pH}$ & $\begin{array}{c}\mathrm{Ca} \\
\mathrm{mg} / 1\end{array}$ & $\begin{array}{c}\mathrm{K} \\
\mathrm{mg} / \mathrm{l}\end{array}$ & $\begin{array}{c}\mathrm{P} \\
\mathrm{mg} / \mathrm{l}\end{array}$ & $\begin{array}{l}\mathrm{Mg} \\
\mathrm{mg} / 1\end{array}$ & $\begin{array}{c}\mathrm{B} \\
\mathrm{mg} / 1\end{array}$ & $\begin{array}{c}\mathrm{Cu} \\
\mathrm{mg} / 1\end{array}$ \\
\hline $0 \ldots$ & 1.2 & 5.3 & 2419 & 127 & 8.1 & 100 & 0.5 & 8.2 \\
\hline $150 \ldots$ & 1.0 & 5.3 & 2325 & 71 & 8.1 & 103 & 0.6 & 8.2 \\
\hline $300 \ldots$ & 1.3 & 5.2 & 2295 & 58 & 7.1 & 102 & 0.6 & 8.2 \\
\hline $450 \ldots$ & 1.4 & 5.1 & 2066 & 56 & 7.0 & 105 & 0.5 & 7.9 \\
\hline
\end{tabular}

siis vapautunut kasveille käyttökelpoiseen muotoon vastaavasti kuin maatalouden tutkimuskeskuksen kokeissa, joissa maan vaihtuvan kaliumin ja ns. reservikaliumin vähennykset pystyivät selittämään vain runsaat puolet nurmien ottaman kaliumin kokonaisvähennyksestä, kun typpilannoitus oli $450 \mathrm{~kg} / \mathrm{ha} \mathrm{N}$ ja kalilannoitus kerta-annoksena keväällä annettuna $100 \mathrm{~kg} / \mathrm{ha} \mathrm{K}$ (Joy ym. 1973). Eräissä tapauksissa kaliumin puute saattoi tällöin rajoittaa sadonmuodostusta (SILlanPÄÄ 1974).

Maan kaliumvarojen väheneminen ei kuitenkaan näissä kokeissa näytä rajoittaneen satoja. Ruohon kuiva-aineen kaliumpitoisuus laski vain vähän alle $3 \%$ kuiva-aineessa, kun kriittisenä rajana kasvun kannalta pidetään $2 \%$ kuiva-aineessa (RINNE 1973). Tätä käsitystä tukee myös seuraava koetulos, joka saatiin Tohmajärven koeasemalla v. 1973 säilörehunurmen kalilannoituskokeessa saraturpeella:

\begin{tabular}{|c|c|c|c|}
\hline $\begin{array}{c}\text { Lannoitus } \\
\mathrm{kg} / \mathrm{ha} \\
\mathrm{K}_{2} \mathrm{O}\end{array}$ & $\begin{array}{c}\text { Sato } \\
\text { t/ha } \\
\text { ka }\end{array}$ & $\begin{array}{c}\mathbf{K} \\
\% \\
\text { kuiva-aineessa }\end{array}$ & $\begin{array}{c}\mathrm{K} \\
\mathrm{mg} / \mathrm{l} \\
\mathrm{maata}\end{array}$ \\
\hline 0 & 11.0 & $2.42-2.37$ & 42 \\
\hline 50 & 10.2 & $2.71-2.63$ & 42 \\
\hline 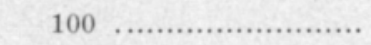 & 10.1 & $2.80-3.15$ & 50 \\
\hline 150 & 10.8 & $2.92-3.25$ & 60 \\
\hline $200 \ldots \ldots \ldots \ldots \ldots \ldots \ldots \ldots$ & 10.2 & $2.87-3.18$ & 82 \\
\hline
\end{tabular}

Ruohon kaliumpitoisuuden pysyessä pienehkönä $2.42-2.37 \%$ kuiva-aineessa (1. ja 3. niitoissa) saatiin jopa korkeampi sato kuin voimakasta kalilannoitusta käytettäessä. Satoerot tosin eivät olleet merkitseviä. Maan vaihtuvan kaliumin määrä oli kokeen alussa $107 \mathrm{mg} / \mathrm{l}$. Kalilannoitus annettiin 2-3 eräässä $50 \mathrm{~kg} / \mathrm{ha} \mathrm{K}_{2} \mathrm{O}$-lannoitusta lukuunottamatta. - Suurimpana syynä satotason laskemiseen käytettäessä voimakasta typpilannoitusta oli näin ollen nurmien harveneminen.

Turpeen sisältämällä kivennäisaineksella lienee ollut merkitystä nurmien kalilähteenä. Maanparannukseen oli kuitenkin käytetty hietaa eikä kaliumrikasta savea, mikä saattaisi juuri säilörehunurmia viljeltäessä olla edullista (vrt. Anttinen 1957, Pessi 1966). 


\section{e. Typpilannoituksen voimaperäisyys}

Markkinattomilla rehukasveilla on taloudellisesti edullisimman lannoituksen määrittely huomattavasti monitahoisempi kysymys kuin muilla peltoviljelykasveilla. Rehun hinnoittelu on usein vaikeaa ja myös rehun valkuaispitoisuus ja muu laatu vaikuttavat lannoituksen järjestelyyn. Kuitenkin joitakin arvioita taloudellisesti edullisimmasta lannoituksesta voidaan esittää.

Keskimääräistä kuiva-ainesatoa eri niittokerroilla kuvaavat seuraavat kvadraattiset funktiot $(\mathrm{x}=100 \mathrm{~kg} / \mathrm{ha} \mathrm{N}, \mathrm{y}=\mathrm{t} / \mathrm{ha} \mathrm{ka})$ :

$$
\begin{aligned}
& y_{1}=2.01+2.31 x-0.99 x^{2} \\
& y_{2}=1.20+1.62 x-0.64 x^{2} \\
& y_{3}=1.76+2.22 x-1.08 x^{2}
\end{aligned}
$$

Yhtälöt osoittavat suoraan, että suurimmat sadot saatiin ensimmäisessä niitossa. Toisessa niitossa sato suureni aluksi vähän hitaammin kuin muissa niitoissa, mutta sadonlisäykset pienenivät vastaavasti hitaammin lannoitusta lisättäessä.

Koko kasvukauden keskisatoa $(\mathrm{Y}=\mathrm{t} / \mathrm{ha} \mathrm{ka})$ kuvaa yhtälö $\mathrm{Y}=4.97+$ $2.07 \mathrm{x}-0.30 \mathrm{x}^{2}$. Maksimisato $\left(\mathrm{y}^{\prime}=0\right.$ ) saatiin tällöin käytettäessä $345 \mathrm{~kg} / \mathrm{ha}$ $\mathrm{N}$ kasvukaudessa.

Taloudellisesti edullisin lannoitus saavutetaan siinä kohdassa, jossa rajatuotto on yhtä suuri kuin rajakustannus eli rajatuotosfunktio $y^{\prime}=P_{x} / P_{y}$, missä $\mathrm{P}_{\mathrm{x}}=$ tuotantovälineen hinta ja $\mathrm{P}_{\mathrm{y}}=$ tuotteen hinta. Koko kasvukauden satoa esittää rajatuotosfunktio $y^{\prime}=2.07-0.60 x=P_{x} / P_{y}$. Jos typen hinta on $110 \mathrm{mk} / 100 \mathrm{~kg}$ ja ry-hinta $30 \mathrm{p}$. eli kuiva-aineen korvauslukua 1.27 käyttäen $236 \mathrm{mk} / \mathrm{t}$, on optimilannoitus $267 \mathrm{~kg} / \mathrm{ha} \mathrm{N}$ kasvukaudessa. Eri niittokertojen satoja kuvaavista yhtälöistä saadaan osalannoituksiksi vastaavasti $93+90+81 \mathrm{~kg} / \mathrm{ha} \mathrm{N}$, joten kokonaistyppimäärä melko tarkasti vastaa edellä esitettyä.

Rajatuotosfunktion avulla voidaan tarkastella hintasuhteiden muutoksen vaikutusta suositeltavaan lannoitemäärään. Jos typen hinta on esimerkiksi $170 \mathrm{mk} / 100 \mathrm{~kg}$, on suositeltava lannoitus $225 \mathrm{~kg} / \mathrm{ha} \mathrm{N}$ rajatuottoajatteluun perustuen. Saatuja lannoitemääriä on kuitenkin pidettävä lähinnä vain suuntaa antavina, sillä lannoituksen järjestelyssä joudutaan ottamaan huomioon samanaikaisesti monia muita tekijöitä kuten edellä jo todettiin. Tarkastelun tulokseen saattaa vaikuttaa myös käytettävä funktiomalli (vrt. IнAмuotiLA 1970).

Keskimääräistä raakavalkuaissatoa kuvaa yhtälö $\mathrm{Y}_{\mathrm{r}}=0.720+0.462 \mathrm{x}$ $-0.0521 \mathrm{x}^{2}$, missä $\mathrm{y}=$ raakavalkuaissato $\mathrm{t} / \mathrm{ha}$ ja $\mathrm{x}=$ lannoitus $100 \mathrm{~kg} / \mathrm{ha}$ N. Vastaava rajatuotosfunktio on $\mathrm{y}_{\mathrm{r}}{ }^{\prime}=0.462-0.104 \mathrm{x}$, jolloin typpikilo $1,10 \mathrm{mk} / 100 \mathrm{~kg}$ ja raakavalkuaisen hinta $2,50 \mathrm{mk} / \mathrm{kg}$ antavat lannoituksen kannattavuusrajaksi $400 \mathrm{~kg} / \mathrm{ha} \mathrm{N}$. Raakavalkuaisen tuottaminen typpilannoituksen avulla on siis kannattavaa varsin suuria typpimääriä käyttäen.

Edellä esitetyn perusteella typpilannoitus $220-240 \mathrm{~kg} / \mathrm{ha}$ typpeä kasvukaudessa näyttää sopivalta lannoitukselta saraturvesuolla. Kolmena osalevityksenä annettuna lannoitus on tarkoituksenmukaista painottaa kevätkesälle. Tällainen menettely on perusteltua myös rehun valkuaispitoisuuden sekä nurmien talvehtimisen kannalta. 


\section{Tiivistelmä}

Artikkelissa tarkasteltiin säilörehuasteella korjatun timotei- ja nurminatanurmen typpilannoitusta saraturvesuolla. Koeaineisto saatiin kenttäkokeista, jotka järjestettiin v. 1970-73 Suoviljelysyhdistyksen Karjalan koeasemalla Pohjois-Karjalassa. Typpilannoituksina annettiin vuosittain 0, 150, 300 ja $450 \mathrm{~kg} / \mathrm{ha}$ typpeä kolmessa yhtä suuressa erässä kasvukauden aikana. Sadot korjattiin kolme kertaa kesässä, mikä määrä oli ruohon kehityksen kannalta sopiva.

Keskimääräistä kuiva-ainesatoa $(\mathrm{Y}=\mathrm{t} / \mathrm{ha})$ kuvasi yhtälö $\mathrm{Y}=4.97+$ $2.07 \mathrm{x}-0.30 \mathrm{x}^{2}$, missä $\mathrm{x}=100 \mathrm{~kg} / \mathrm{ha} \mathrm{N}$. Typen satoa lisäävä vaikutus oli paras ensimmäisen vuoden nurmissa. Tällöin saatiin kuiva-ainesadon lisäystä $\mathrm{N}$-kiloa kohti lannoitusvälillä $150-300 \mathrm{~kg} / \mathrm{ha} \mathrm{N}$ keskimäärin $6.9 \mathrm{~kg}$, toisen vuodèn nurmissa $3.1 \mathrm{~kg}$ ja kolmannen vuoden nurmissa $0.5 \mathrm{~kg}$. Käytettäessä $150 \mathrm{~kg} / \mathrm{ha} \mathrm{N}$ nurmen tuottokyky ei merkittävästi alentunut kolmen vuoden aikana.

Suurimpana syynä satotason laskemiseen käytettäessä voimakasta typpilannoitusta oli nurmien harveneminen, jota pääasiassa tapahtui talven aikana.

Ruohon kuiva-aineen raakavalkuaispitoisuus oli alhaisin ensimmäisen niittokerran sadossa. Typpilannoitus $50 \mathrm{~kg} / \mathrm{ha} \mathrm{N}$ niittokertaa kohti nosti toisen sadon raakavalkuaispitoisuuden keskimäärin 19.2 ja kolmannen sadon $18.3 \%$ :iin kuiva-aineessa.

Typpilannoitus lisäsi ensimmäisten satojen kaliumpitoisuutta. Nurmet ottivat kaliumia selvästi yli kasvun edellyttämän tarpeen.

Ruohon magnesiumpitoisuus oli alhaisin ensimmäisen niittokerran sadossa. Typpilannoitus lisäsi yleensä magnesiumin osuutta kuiva-aineessa. Ruohon nitraattipitoisuus nousi erittäin selvästi typpilannoituksen vaikutuksesta.

Vaikka vaihtuvan kalsiumin määrä turpeessa pieneni voimakkaan typpilannoituksen yhteydessä, pH:n muutos jäi vähäiseksi. Turpeen sisältämä kalium väheni selvästi voimakasta typpilannoitusta käytettäessä.

Sopivimmaksi typpimääräksi säilörehunurmelle osoittautui $220-240 \mathrm{~kg} / \mathrm{ha}$ $\mathrm{N}$, mikä kolmeen osaan jaettuna oli edullisinta painottaa kevätkesälle.

\section{KIRJALLISUUSLUETTELO}

Antrinen, O. 1957. Saraturvesuon saveus- ja lannoituskokeen tuloksia. Referat: Ergebnisse eines Lehmzufuhr- und Düngungsversuchs auf Seggentorfmoor. Valt. Maatal. koetoim. Julk. 163: $1-20$.

Ettala, E., Nenonen, E. \& Lamprl., M. 1972. Nurmisäilörehujen säilöntätappioista. Referat: Konserveringsförluster för vallgräsensilage. Kehittyvä Maatalous 7:16-28.

HuокUNA, E. 1971. Valkuaispitoisen AIV-rehun tuottaminen heinïvaltaisilla nurmilla. Karjatalous 47: 92-93.

-, 1971. Runsaan typpilannoituksen saaneiden nurmien talvehtiminen. Karjatalous 47: 334-335 .

_- 1973. Valkuaisen tuotanto nurmilla. Koetoim. ja Käyt. 30:12. 
IнамuотіLA R. 1970. The effect of increasing nitrogen fertilization on the economic result in corn production. Selostus: Lisääntyvän typpilannoituksen vaikutuksesta maissintuotannon taloudelliseen tulokseen New Yorkin valtiossa. Maat. Tal.tutk.lait. Julk. 21: $1-28$.

Joy, P., Lakanen, E \& Sillanpän̈, M. 1973. Effects of heavy nitrogen dressings upon release of potassium from soils cropped with ley grasses. Selostus: Nurmille annettujen suurten typpilannoitusmäärien vaikutus maan kaliumiin. Ann. Agric. Fenn. 12: 172-184.

JÄNrrı, A. 1967. Runsaan typpilannoituksen hyväksikäyttö laidunsäilörehunurmilla. Karjatalous 44: $82-85$.

Kurki, M., Lakanen, E., Mäkitie, O., Sillanpää, M. \& Vuorinen, J. 1965. Viljavuusanalyysin tulosten ilmoitustapa ja tulkinta. Summary: Interpretation of soil testing results. Ann. Agric. Fenn. 4: 145-153.

Pessi, Y. 1966. Suon viljely. 139 p. Porvoo.

PoutrarneN, E. \& Rinne, K. 1971. Korjuuasteen vaikutus säilörehun ravintoarvoon. Referat: Inverkan av skördestadium på ensilagets fodervärde. Kehittyvä Maatalous 3: $15-28$.

- RrNNe, S.-L. 1973. Runsaan typpilannoituksen vaikutus säilörehuasteella olevan nurminadan ja koiranheinän kivennäisainepitoisuuteen. Koetoim. ja Käynt. 9-10:30-31.

Salonen, M., TAInıo, A. \& TÄhtinen, H. 1962. Typpilannoitusta koskevia tutkimuksia. Summary: Investigations on nitrogen fertilization. Ann. Agric. Fenn. 1: 133-174.

6 SillanpäÄ, M. 1974. Nurmille annettujen suurten typpilannoitemäärien vaikutus maan kalivaroihin. Koetoim. ja Käyt. 31: 9 .

TENnberg, F. 1955. Niittonurmien pintalannoituksesta. Maatal. ja Koetoim. 9:47-57.

_- \& VAlmari, M. 1969. Normaalin Y-lannoksen, Oulun Y-lannoksen ja väkevän Oulun Y-lannoksen vertailevat kokeet nurmella. Summary: Comparative experiments with three various compounded fertilizer on ley. Ann. Agric. Fenn. 8: 286-315. 